\title{
DAFTAR PEGUNJUNG PERPUSTAKAAN BERBASIS ELEKTRONIK DI PERPUSTAKAAN STIKES ALIFAH PADANG
}

\author{
Putri Meri Yanti Pertiwi*), Marlini **) \\ Prodi Informasi Perpustakaan dan Kearsipan. Jurusan Bahasa dan sastra Indonesia dan Daerah \\ Fakultas Bahasa dan seni Universitas Negeri Padang, Indonesia \\ email: putrimeriyanti@gmail.com*),marlininasr@yahoo.com**),
}

Naskah diterima: 16 April; direvisi: 30 April; disetujui: 2 Mei 2020

\begin{abstract}
Abstrak
Terjadinya perubahan dalam melakukan kegiatan layanan perpustakan seperti, dalam menerapkan sistem daftar pengunjung berbasis elektronik di perpustakaan stikes alifah padang, membuat pemustaka dan pustakawan menjadi mudah dalam mengakses daftar pengujung yang akan mengujungi perpustakaan stikes alifah padang. Dan dimanfaatkan untuk melihat jumlah kunjungan terkait dengan sarana dan prasarana yang disediakan dan pelayanan yang diberikan. Pengunjung enggan untuk mengisi buku tamu, dikarenakan proses pengisiannya yang harus mengantri terutama pada saat ramai pengunjung, sehingga data yang tertera pada buku tamu tidak dapat mewakili kondisi yang sesungguhnya. Akibatnya buku tamu hanya menjadi pelengkap administrasi saja.Secara administratif, pengunjung yang datang diminta untuk mengisi buku tamu terlebih dahulu, selanjutnya dapat melakukan aktifitas membaca ataumeminjam koleksi bahan pustaka. Untuk mengukur tingkat layanan yang diberikan, hanya dilakukan dengan mengamati secara fisik aktifitas yang ada dan berdasarkan keluhan yang disampaikan pengunjung.
\end{abstract}

Kata Kunci: Daftar elektronik; layanan elektronik; pemustaka

\begin{abstract}
Changes occur in carrying out library service activities such as, implementing an electronicbased visitor list system at the Alifah Padang stikes library, making it easy for users and librarians to access the list of visitors who will visit the Alifah Padang stikes library. And used to see the number of visits related to the facilities and infrastructure provided and services provided. Visitors are reluctant to fill in the guest book because the filling process must be queued, especially during crowded visitors, so the data contained in the guest book cannot represent the real condition. As a result, the guest book only complements administration. Administratively, visitors who come are asked to fill in the guest book first, they can do the reading or borrowing collection of library materials. To measure the level of service provided, only done by physically observing the existing activities and based on complaints submitted by visitors.
\end{abstract}

Keyword: Electronic list; electronic services; user 


\section{PENDAHULUAN}

Perpustakaan merupakan unit yang memiliki fungsi penting dalam penyediaan bahan pustaka untuk pendidikan, penelitian dan pengabdian kepada masyarakat. Untuk memberikan layanan yang baik, selain melengkapi dengan bahan bacaan yang beragam, jumlah SDM yang cukup, ruang baca yang nyaman, tersedia juga layanan sistem informasi yang dapat di akses secara online untuk memudahkan pengunjung menemukan bahan bacaan yang dibutuhkan. Manfaat yang bisa dipetik dari penerapan teknologi informasi di perpustakaan antara lain: Memberikan layanan yang lebih baik kepada pengguna perpustakaan, meningkatkan citra perpustakaan dan pembangunan infrastruktur nasional, regional dan global (Sunu, 2014).

Perpustakaan sangat bermanfaat dalam penyelenggaraan proses belajar di kalangan masyarakat, sehingga setiap perpustakaan diwajibkan untuk menyediakan koleksi dan fasilitas yang memadai. Perpustakaan merupakan salah satu bagian dari gerbang menuju pengetahuan perkembangan ilmu teknologi semakin pesat. Perpustakaan yang merupakan pusat pelayanan informasi sudah seharusnya mengikuti perkembangan tersebut secara efektif dan efesien. Saat ini, buku tamu elektronik merupakan inovasi baru dalam dunia digital yang sangat tepat digunakan dalam pelayanan perpustakaan. Badan Arsip dan Perpustakaan Aceh merupakan salah satu perpustakaan yang telah menggunakan buku tamu elektronik.

Dalam perpustakaan setiap harinya pasti terdapat banyak orang yang melakukan aktivitas seperti membaca, meminjam buku serta mengembalikan buku yang telah dipinjam. Pelayanan dari aktivitas-aktivitas tersebut dan pengelolaan data perpustakaan yang dilakukan secara terkomputerisasi dalam sebuah sistem informasi perpustakaan tentunya mempermudah petugas perpustakaan dalam pengelolaan data perpustakaan, transaksi peminjaman dan pengembalian buku serta mempermudah pengunjung perpustakaan dalam memperoleh informasi dari perpustakaan.

Pihak perpustakaan memanfaatkan buku tamu elektronik sebagai alat bantu untuk mengetahui pengguna perpustakan Perpustakaan StiKes Alifah. Dengan demikian, Perpustakaan StiKes Alifah dapat menyediakan koleksi sesuai dengan kebutuhannya. Pemenuhan informasi kepada pengguna dipengaruhi oleh ketersediaan koleksi yang berkaitan dengan pengadaan. Dalam proses pengadaan koleksi, pihak perpustakaan harus mengetahui betul apa tujuan perpustakaan dan siapa pemakainya. Setiap perpustakaan melayani kelompokkelompok pemakai dengan ciri-ciri tertentu, sehingga diperlukan perencanaan yang matang dan sesuai dengan kebutuhan pengguna.

Secara administratif, pengunjung yang datang diminta untuk mengisi buku tamu terlebih dahulu, selanjutnya dapat melakukan aktifitas membaca atau meminjam koleksi bahan pustaka. Untuk mengukur tingkat layanan yang diberikan, hanya dilakukan dengan mengamati secara fisik aktifitas yang ada dan berdasarkan keluhan yang disampaikan pengunjung. Buku tamu merupakan alat bantu untuk mengetahui seberapa banyak orang datang ke suatu tempat, instansi atau perpustakaan. Penggunaan buku tamu pada dasarnya hanya untuk mendata pengunjung atau yang datang ke suatu tempat atau perpustakaan. Dengan adanya buku tamu elektronik pustakawan lebih mudah dalam memperoleh data pengunjung untuk disimpan, diorganisir, diolah dan dapat ditemukan kembali sekian banyak data yang diperlukan, serta mengumpulkan semua data menjadi data yang terpadu laporan tahunan, selain itu buku tamu berfungsi sebagai alat memonitor perkembangan pengunjung perpustakaan tiap tahun.

Buku tamu elektronik adalah sebagai salah satu alat yang dimanfaatkan perpustakaan dalam memberikan pemenuhan kebutuhan bagi pengguna dan melihat siapa saja pengguna perpustakaan sehingga perpustakaan bisa lebih mudah dalam mengembangkan koleksi atau melakukan pengadaan koleksi.

Secara administratif, pengunjung yang datang diminta untuk mengisi buku tamu terlebih dahulu, selanjutnya dapat melakukan aktifitas membaca atau meminjam koleksi bahan pustaka. Untuk mengukur tingkat layanan yang diberikan, hanya dilakukan dengan mengamati secara fisik aktifitas yang ada dan berdasarkan keluhan yang disampaikan pengunjung.

Buku tamu merupakan alat bantu untuk mengetahui seberapa banyak orang datang ke suatu tempat, instansi atau perpustakaan. Penggunaan buku tamu pada dasarnya hanya untuk mendata pengunjung atau yang datang ke suatu tempat atau perpustakaan. Dengan adanya buku tamu elektronik pustakawan lebih mudah dalam memperoleh data. pengunjung untuk 
disimpan, diorganisir, diolah dan dapat ditemukan kembali sekian banyak data yang diperlukan, serta mengumpulkan semua data menjadi data yang terpadu (Nasrul Lubis, 2007).

Buku tamu yang digunakan pada perpustakaan Stikes alifah padang berupa buku yang mencantumkan identitas pengunjung seperti No. Induk, Nama, tanggal kehadiran dan tanda tangan yang wajib diisi oleh setiap pengunjung, baik mahasiswa, dosen ataupun tamu yang berkunjung ke perpustakaan. Pada saat terjadi peningkatan jumlah pengunjung, terjadi antrian panjang sehingga membuat pengunjung tidak nyaman dan sebagian pengunjung memilih untuk tidak mengisi buku tamu.

\section{LANDASAN TEORI}

\section{A. Fungsi dan tujuan buku tamu}

Elektronik Dalam memenuhi kebutuhan masyarakat pengguna dan kemudahan kerja pustakawan, buku tamu elektronik menjadi salah satu alat bantu pencarian data bagi pustakawan. Adapun fungsi buku tamu elektronik, antara lain :

1) Mengetahui data jumlah banyaknya tamu yang berkunjung.

2) Mengenal data tamu lebih dekat seperti nama, alamat, dan lain-lain.

3) Mengetahui tujuan pengunjung perpustakaan.

4) Untuk mengetahui perkembangan pengunjung perpustakaan tiap tahunnya.

5) Bentuk kedekatan antara pengunjung dengan perpustakaan (Danu Winarko , 2013).

\section{B. Kelebihan buku tamu elektronik dengan buku tamu manual}

Buku tamu elektronik merupakan salah satu alat untuk mendata pengunjung dan mengetahui tingkat statistik pengunjung perpustakaan. Buku tamu elektronik merupakan pengalihan dari buku tamu manual yaitu yang masih menggunakan cara menuliskan dengan pulpen pada media buku dalam pengisian dan pencarian data pengunjung. Cara ini dirasakan masih mengalami hambatan dan selalu terjadi kesalahan dalam perhitungan jumlah pengunjung perpustakaan, sehingga kurang efektif dalam pembuatan laporan. Kelemahan buku tamu manual adalah sebagai berikut :

1) Keamanan dan pemeliharaan data tidak terjamin

2) Tingkat kesalahan yang lebih besar dalam proses perhitungan

3) Pembuatan laporan tidak efisien.
Berdasarkan uraian tersebut maka laporan yang dihasilkan terkadang masih mengalami kekeliruan, tidak akurat, tidak up to date dan sering mengalami keterlambatan pembuatan dan penyampaian laporan (Rushendi, 2016).

Buku tamu elekronik merupakan suatu alat yang dimanfaatkan perpustakaan dalam memberikan pemenuhan kebutuhan bagi pengguna yaitu dengan melihat siapa saja pengguna perpustakaan sehingga perpustakaan bisa lebih mudah dalam mengembangkan koleksi atau melakukan pengadaan koleksi. Pemenuhan informasi kepada pengguna dipengaruhi oleh ketersediaan koleksi yang berkaitan dengan pengadaan. Dalam proses pengadaan koleksi, pihak perpustakaan harus mengetahui betul apa tujuan perpustakaan dan siapa pemakainya.

\section{Pengertian antrian}

Merupakan bagian dari kehidupan manusia sehari-hari. Antrian terbentuk bilamana banyaknya yang akan dilayani melebihi kapasitas layanan yang tersedia. Dalam banyak hal, penambahan jumlah layanan dapat dipenuhi untuk mengurangi antrian atau menghindari antrian yang terus membesar; namun demikian, biaya penambahan layanan dapat menyebabkan keuntungan berada di bawah taraf yang dapat diterima. Dipihak lain, antrian yang terlalu panjang dapat mengakibatkan kehilangan penjualan ataupun pelanggan

\section{Komponen Sistem Antrian Komponen Dasar Proses Antrian Adalah:}

Kedatangan Setiap masalah antrian melibatkan kedatangan, misalnya orang, mobil, panggilan telepon untuk dilayani, dan lain-lain. Unsur ini sering dinamakan proses input. Proses input meliputi sumber kedatangan atau biasa dinamakan calling population, dan cara terjadinya kedatangan yang umumnya merupakan variabel acak.

Pelayan atau mekanisme pelayanan dapat terdiri dari satu atau lebih pelayan, atau satu atau lebih fasilitas pelayanan. Tiap-tiap fasilitas pelayanan kadang-kadang disebut sebagai saluran (channel). Contohnya, jalan tol dapat memiliki beberapa pintu tol. Mekanisme pelayanan dapat hanya terdiri dari satu pelayan dalam satu fasilitas pelayanan yang ditemui pada loket seperti pada penjualan tiket di gedung bioskop. 3. Antri Inti dari analisa antrian adalah antri itu sendiri. Timbulnya antrian terutama tergantung dari sifat kedatangan dan proses pelayanan. Jika tak ada antrian berarti terdapat pelayan yang menganggu. 


\section{Struktur antrian}

Ada 4 model struktur antrian dasar yang umum terjadi dalam seluruh sistem antrian:

1. Single Channel - Single Phase Single Channel berarti hanya ada satu jalur yang memasuki sistem pelayanan atau ada satu fasilitas pelayanan. Single Phase berarti hanya ada satu pelayanan.

2. Single Channel - Multi Phase Istilah Multi Phase menunjukkan ada dua atau lebih pelayanan yang dilaksanakan secara berurutan (dalam phasephase). Sebagai contoh : pencucian mobil.

3. Multi Channel - Single Phase Sistem Multi Channel - Single Phase terjadi kapan saja di mana ada dua atau lebih fasilitas pelayanan dialiri oleh antrian tunggal, sebagai contoh model ini adalah antrian pada teller sebuah bank

4. Multi Channel - Multi Phase Contoh model Multi Channel-Multi Phase yaitu, registrasi para mahasiswa di universitas, pelayanan kepada pasien di rumah sakit mulai dari pendaftaran, diagnosa, penyembuhan sampai pembayaran. Setiap sistem-sistem ini mempunyai beberapa fasilitas pelayanan pada setiap tahapnya

\section{METODE PENELITIAN}

Penelitian ini dilaksanakan melalui tahapan kegiatan penelitian sebagai berikut:

a. Perumusan masalah Tahap awal penelitian ini dilakukan dengan mengidentifikasi berbagai permasalahan dalam pengelolaan buku tamu di perpustakaan STIKes Alifah, mempelajarinya dan selanjutnya merumuskan masalah penelitian.

b. Pengumpulan Data Kegiatan pengumpulan data dilaksanakan melalui wawancara, dan pengamatan langsung dan mengumpulkan berbagai artikel penelitian yang berkaitan dengan bidang yang penulis teliti, khususnya mengenai pemanfaatan teknologi barcode dalam pengembangan apilkasi berbasis web.

\section{HASIL DAN PEMBAHASAN}

Buku tamu yang digunakan pada perpustakaan Stikes alifah padang merupakan buku tamu fisik yang diisi oleh pengunjung, baik anggota (mahasiswa, dosen dan staf) maupun tamu yang datang berkunjung. Informasi yang terangkum di dalamnya adalah tanggal kunjungan, nama pengunjung, no identitas (NIM bagi mahasiswa dan NIK bagi staf / dosen) dan paraf.

Perpustakaan STIKes Alifah memakai daftar pengunjung berbasis elektronik dan menerapkan dengan cara, pertama menggunakan registrasi nama jadi kalau mahasiswa berkujung mereka harus menginput nim yang telah ditetapkan oleh staf kemahasiswaan yang ada di STIKes Alifah yang di masukan ke komputer yang sudah di sediakan, kedua yaitu dengan memasukan halaman yang di sediakan untuk memasukan nim, nim di masukan kesana agar bisa di baca oleh komputer untuk mendeteksi agar pengunjung dari mahasiswa STIKes Alifah terdeteksi sebagai mahasiswa STIKes Alifah untuk masuk ke dalam daftar pengunjung perpustakaan STIKes Alifah padang

Daftar pengunjung di STIKes Alifah berhubungan langsung dengan aplikasi opac yang biasa digunakan untuk mencari buku yang ada pada perpustakaan STIKes Alifah Padang, di opac telah di sediakan seperti registrasi untuk masuk ke daftar pengunjung dan nanti mahasiswa STIKes Alifah untuk memasukan nim yang telah di sediakan oleh STIKes untuk akses ketika masuk ke dalam perpustakaan.

Perpustakaan STIKes Alifah juga menyediakan tamu dari luar atau mahasiswa luar untuk meminjam buku dengan cara akses menggunakan buku tamu yang telah di sediakan dengan cara menggunakan kartu nama yang di sediakan oleh STIKes Alifah dan di tambahkan sebagai anggota baru di perpustakaan Alifah dan nanti di berikan username /Id untuk login.

Tahun diterapkan nya penggunaaan daftar pengunjung STIKes Alifah berbasis elektronik semenjak tahun 2003, dalam penggunaan daftar pengunjung berbasis elektronik mempunyai tujuan yaitu mengikuti perkembangan perpustakaan dan agar tidak adanya antrian dalam proses pengambilan daftar pengunjung di perpustakaan STIKes Alifah Padang.

Penggunaan daftar pengunjung berbasis elektronik di STIKes Alifah adalah Single Channel - Single Phase Single Channel berarti hanya ada satu jalur yang memasuki sistem pelayanan atau ada satu fasilitas pelayanan. Single Phase berarti hanya ada satu pelayanan

STIKes Alifah menggunakan single channel - single channel karena di STIKes alifah melakukan pengantrian berurutan dengan cara 
memasukan nim yang telah disediakan oleh aplikasi, pengunaan dengan cara single channel ini sangat berguna agar para pengunjung perpustakaan bisa mengakses secara cepat untuk pengisian daftar pengunjung, pengunaan single channel - single channe ini menghindari antrian yang panjang ketika pustakawan ingin masuk ke dala perpustakaan secara banyak.

Buku tamu yang di gunakan ketika daftar pengunjung elektronik tidak berfungsi yaitu kita mengunakan buku manual yang berbentuk buku pengunjung biasa seperti di sediakan pada perpustakaan universitas lain.

Buku tamu ini ditempatkan di dekat pintu masuk perpustakaan. Selain buku tamu fisik terdapat pula buku tamu (guest book) yang disediakan di sistem informasi perpustakaan yang diperuntukkan bagi pengunjung website perpustakaan.

Hasil analisa pada penggunaan buku tamu di perpustakaan Stikes alifah padang saat ini adalah sebagai berikut:

a. Pada saat jumlah kunjungan meningkat, terjadi antrian pengisian buku tamu, sehingga banyak yang memilih langsung masuk ke perpustakaan tanpa mengisi buku tamu. Sehingga data pada buku tamu tidak dapat mewakili jumlah kunjungan yg sesungguhnya.

b. Kesulitan dalam merekap data dari buku tamu, dibutuhkan ketelitian dan waktu yang cukup lama, sehingga pihak manajemen tidak bisa dengan segera mendapatkan informasi terkait statistik kunjungan di perpustakaan, buku tamu hanya dijadikan sebagai pelengkap administratif saja. Berdasarkan informasi yang diperoleh dari buku tamu fisik, jumlah pengunjung yang meminjam buku. umlah pengunjung yang tercatat pada buku tamu. Pengunjung yang melakukan peminjaman hanya sebesar $13,28 \%$ atau 1.260 orang dari total pengunjung perpustakaan sebanyak 9.482 orang. Ini belum termasuk pengunjung yang tidak terdata melalui buku tamu yang mencapai hampir 50\% dari total pengunjung setiap harinya.

c. Struktur data kurang lengkap, sehingga tidak bisa memenuhi kebutuhan informasi terkait kapan waktu terjadinya kunjungan, berapa lama mereka berada di perpustakaan, tingkat kepuasan atas layanan di perpustakaan serta hal-hal lainnya yang terkait dengan aktifitas pengunjung di perpustakaan.

d. Perpustakaan StiKes Alifah sudah ditunjang dengan keberadaan Sistem Informasi Perpustakaan dan Digital Library. Fitur yang umumnya digunakan oleh pengunjung adalah pencarian katalog untuk membantu pengunjung menemukan langsung koleksi bacaan yang dibutuhkannya, karena telah disertai dengan informasi ketersediaan bahan bacaan dan letaknya. Namun pihak manajemen tidak punya informasi yang detail tentang jenis koleksi bacaan apa yang paling diminati atau yang paling dicari. Padahal informasi ini sangat penting untuk pengambilan keputusan tentang penambahan koleksi bacaan dan jumlah eksemplar yang dibutuhkan

Pada dasarnya tugas utama setiap perpustakaan adalah membangun koleksi dan menyediakan informasi yang kuat untuk memenuhi kebutuhan masyarakat pengguna perpustakaan. Untuk memenuhi kebutuhan informasi bagi masyarakat pengguna, perpustakaan harus mampu

1) mengkaji/mengenali siapa masyarakat pemakainya dan informasi apa yang diperlukannya,

2) mengusahakan tersedianya jasa pada saat diperlukan, serta

3) mendorong pemakai untuk menggunakan fasilitas yang disediakan oleh perpustakaan. Analisis pemakai dan kebutuhan pemakai ini ditujukan untuk pengembangan koleksi perpustakaan demi tersedianya kebutuhan informasi yang benar-benar mutakhir dan relevan (Syiahbuddin \& dkk, 2007)

Sistem Pelayanan Sistem pelayanan perpustakaan di bagi menjadi dua macam yaitu:

1) Sistem pelayanan terbuka (opened access) yaitu suatu sistem pelayanan perpustakaan dimana pengunjung diberi kebebasan untuk mencari dan mengambil sendiri buku-buku yang dikehendaki. 
2) Sistem pelayanan tertutup (closed access) yaitu sistem pelayanan perpustakaan dimana pengunjung tidak diberi kebebasan untuk mencari dan mengambil sendiri bahan pustaka yang dikehendaki. Berdasarkan pengertian di atas maka perpustakaan yang menjadi bahan penelitian ini menggunakan sistem pelayanan terbuka, dimana pengunjung diberi kebebasan untuk mencari dan mengambil sendiri buku-buku koleksi perpustakaan.

\section{Hasil Analisis Sistem Administrasi Perpustakaan}

Sistem administrasi perpustakaan yang sedang berjalan yang meliputi proses pencatatan dan rekapitulasi data secara manual dengan menggunakan buku/kertas tentunya akan membuat kinerja operasional tidak efisien karena membutuhkan banyak waktu untuk mencari dan mengumpulkan informasi-informasi tertentu, misalnya informasi data buku, data peminjaman, data anggota dan lain sebagainya. Dalam sistem usulan akan dirancang suatu sistem yang dapat mengubah seluruh proses yang dilakukan secara manual menjadi terkomputerisasi, otomatis dan sistematis.

\section{Solusi Permasalahan Sistem}

Untuk mengatasi berbagai permasalahan di atas, diperlukan suatu teknik baru dalam perekaman data pengunjung di perpustakaan yang memanfaatkan teknologi informasi. Buku Tamu elektronik memiliki keunggulan berupa kemampuan merekam data pengunjung secara lebih cepat dan akurat, dan menghasilkan informasi sesuai jumlah kunjungan yang terjadi.

Buku Tamu Elektronik yang akan di rancang ditujukan untuk mempercepat proses perekaman data pengunjung melalui penggunaan teknologi barcode, sehingga dapat mengurangi antrian, mempercepat proses pengolahan informasi dan menyimpan informasi yang lebih lengkap, seperti profil pengunjung, tingkat kepuasan terhadaplayanan, sarana penunjang dan kelengkapan dan kemudahan memperoleh bahan bacaan yang diperlukan.

\section{Analisis Kebutuhan Sistem}

Buku tamu elektronik merupakan aplikasi yang dibangun untuk menggantikan peran buku tamu fisik yang memiliki keterbatasan seperti yang telah diuraikan sebelumnya. Aplikasi buku tamu elektronik memiliki fungsionalitas sebagaimana yang tersaji pada gambar 1 .

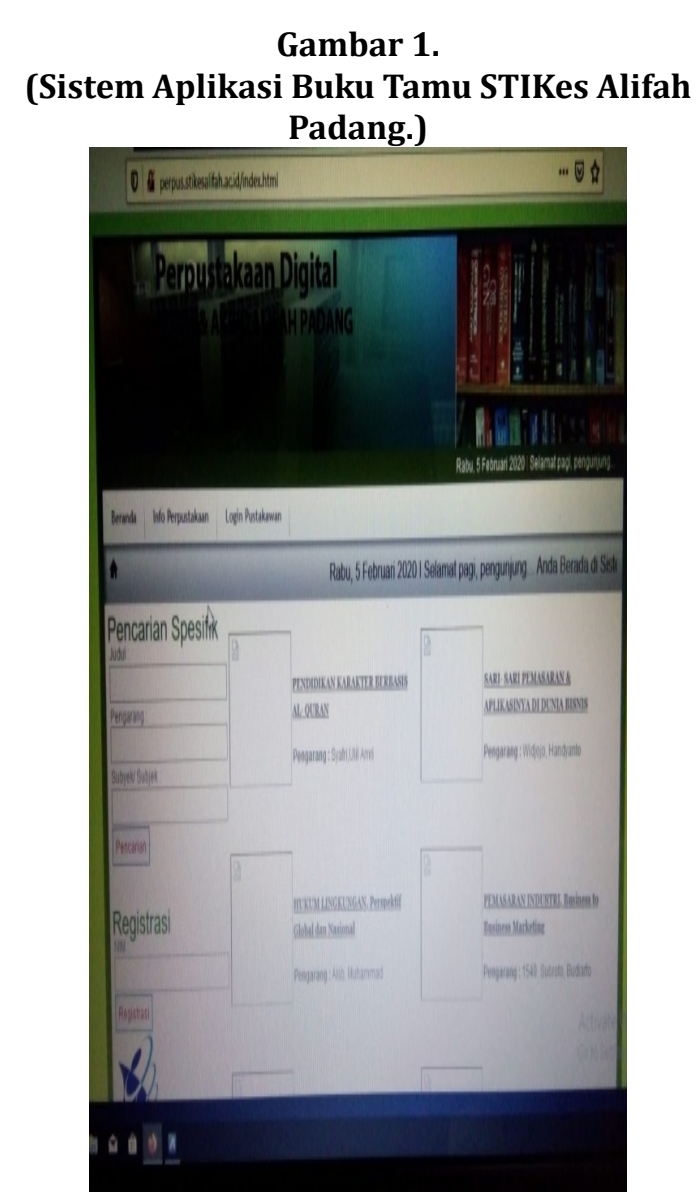

Pada gambar 1 sistem pengambilan daftar hadir tamu di Perpustakaan StiKes Alifah dengan format registrasi yang ditampilkan dalam sistem buku elektronik. Dalam sistem tersebut kita dapat mengakses pencarian buku yang ada pada di sistem tersebut. Sistem informasi perpustakaan ini memiliki beberapa kelebihan diantaranya yaitu anggota perpustakaan dapat melihat koleksi buku dan stok buku pada perpustakaan dengan melakukan pencarian buku (searching) pada aplikasi perpustakaan ini sehingga mempermudah anggota perpustakaan dalam memperoleh informasi mengenai buku yang terdapat di perpustakaan. Petugas perpustakaan juga tidak akan kesulitan dalam penghitungan denda karena dalam aplikasi ini terdapat penghitungan denda secara otomatis berdasarkan tanggal peminjaman dan tanggal pengembalian buku serta dalam pembuatan laporan peminjaman buku. Aplikasi ini juga menggunakan database sehingga semua data akan tersimpan dengan rapi, terjamin keamanan dan keakuratan datanya dan proses pendataan buku dapat dilakukan dengan cepat, tepat dan akurat.

Gambar 2

(Sistem login Buku Tamu Elektronik) 


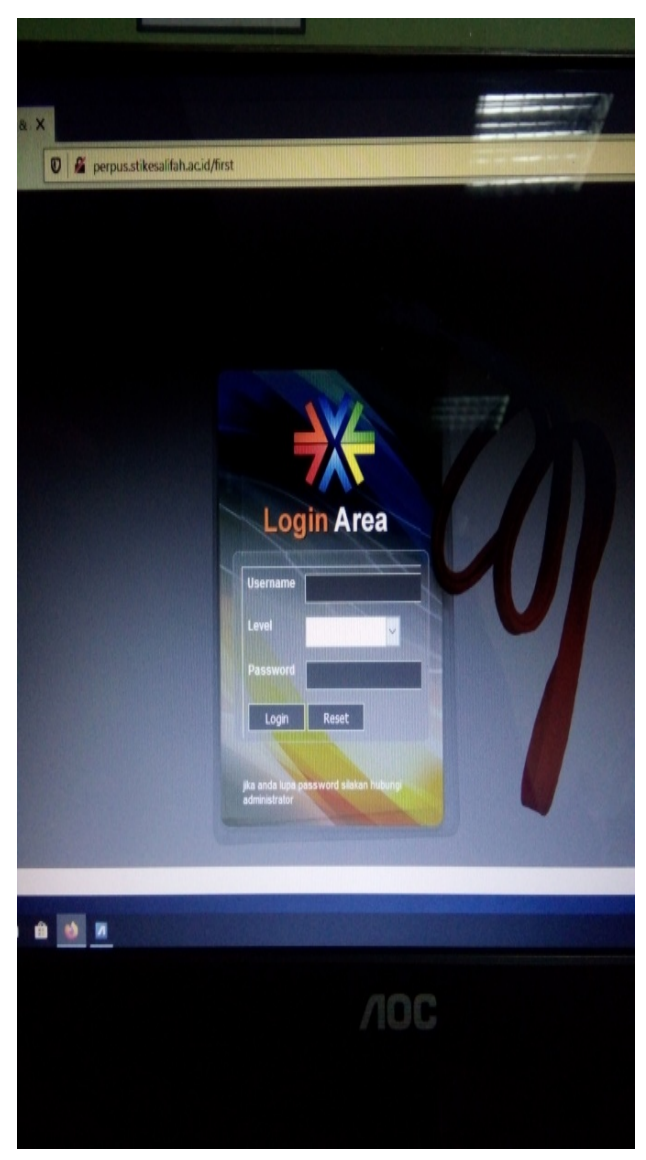

Pada gambar 2 dijelaskan bagaimana cara login di perpustakaan StiKes Alifah Padang terdapat beberapa yang harus di isi pertama username dari mahasiswa di StiKes Alifah Padang kedua user, user yang di maksud adalah kita masuk sebagai mahasiswa atau umum dan kalau kita berasal dari mahasiswa StiKes Aifah kita menggunakan password lalu kita login. Siapa pun yang hadir di perpustakaan, termasuk anggota, yang dapat melakukan aktifitas seperti mengisi data kunjungan buku tamu elektronik, mendaftar sebagai anggota perpustakaan, mencari katalog bahan bacaan, membuat usulan untuk penyediaan bahan pustaka serta menyampaikan kritik maupun saran terkait layanan di perpustakaan

\section{SIMPULAN}

Dari hasil penggunaan buku tamu berbasis elektronik dapat kita ambil kesimpulan nya adaalah dengan menggunakan aplikasi tersebut kita bisa ambil positif nya yaitu kita bisa tau beberapa orang perhari berkunjung dalam beberapa hari bahkan beberapa bulan dan tahun maka penggunaan ini efektif kalau dilakukan di perpustakaan mana pun apabila perpustakaan tersebut ingin melihat secara mudah statistik pengunjung.
Perpustakaan STIKes Alifah memakai daftar pengunjung berbasis elektronik dan menerapkan dengan cara, pertama menggunakan registrasi nama jadi kalau mahasiswa berkujung mereka harus menginput nim yang telah ditetapkan oleh staf kemahasiswaan yang ada di STIKes Alifah yang di masukan ke komputer yang sudah di sediakan, kedua yaitu dengan memasukan halaman yang di sediakan untuk memasukan nim, nim di masukan kesana agar bisa di baca oleh komputer untuk mendeteksi agar pengunjung dari mahasiswa STIKes Alifah terdeteksi sebagai mahasiswa STIKes Alifah untuk masuk ke dalam daftar pengunjung perpustakaan STIKes Alifah padang

Daftar pengunjung di STIKes Alifah berhubungan langsung dengan aplikasi opac yang biasa digunakan untuk mencari buku yang ada pada perpustakaan STIKes Alifah Padang, di opac telah di sediakan seperti registrasi untuk masuk ke daftar pengunjung dan nanti mahasiswa STIKes Alifah untuk memasukan nim yang telah di sediakan oleh STIKes untuk akses ketika masuk ke dalam perpustakaan.

Di perpustakaan STIKes Alifah juga menyediakan tamu dari luar atau mahasiswa luar untuk meminjam buku dengan cara menggunakan buku tamu yang telah di sediakan dengan cara menggunakan kartu nama yang di sediakan oleh STIKes Alifah dan di tambahkan sebagai anggota baru di perpustakaan Alifah dan nanti di berikan username /Id untuk login.

Tahun diterapkan nya penggunaaan daftar pengunjung STIKes Alifah berbasis elektronik semenjak tahun 2003, dalam penggunaan daftar pengunjung berbasis elektronik mempunyai tujuan yaitu mengikuti perkembangan perpustakaan dan agar tidak adanya antrian dalam proses pengambilan daftar pengunjung di perpustakaan STIKes Alifah Padang.

Penggunaan daftar pengunjung berbasis elektronik di STIKes Alifah adalah

Single Channel - Single Phase Single Channel berarti hanya ada satu jalur yang memasuki sistem pelayanan atau ada satu fasilitas pelayanan. Single Phase berarti hanya ada satu pelayanan

STIKes Alifah menggunakan single channel - single channel karena di STIKes alifah melakukan pengantrian berurutan dengan cara memasukan nim yang telah disediakan oleh aplikasi, pengunaan dengan cara single channel 
ini sangat berguna agar para pengunjung perpustakaan bisa mengakses secara cepat untuk pengisian daftar pengunjung, pengunaan single channel - single channe ini menghindari antrian yang panjang ketika pustakawan ingin masuk ke dala perpustakaan secara banyak.

Ada 4 model struktur antrian dasar yang umum terjadi dalam seluruh sistem antrian:

a. Single Channel - Single Phase Single Channel berarti hanya ada satu jalur yang memasuki sistem pelayanan atau ada satu fasilitas pelayanan. Single Phase berarti hanya ada satu pelayanan.

b. Single Channel - Multi Phase Istilah Multi Phase menunjukkan ada dua atau lebih pelayanan yang dilaksanakan secara berurutan (dalam phasephase). Sebagai contoh : pencucian mobil.

c. Multi Channel - Single Phase Sistem Multi Channel - Single Phase terjadi kapan saja di mana ada dua atau lebih fasilitas pelayanan dialiri oleh antrian tunggal, sebagai contoh model ini adalah antrian pada teller sebuah bank

d. Multi Channel - Multi Phase Contoh model Multi Channel - Multi Phase yaitu, registrasi para mahasiswa di universitas, pelayanan kepada pasien di rumah sakit mulai dari pendaftaran, diagnosa, penyembuhan sampai pembayaran. Setiap sistem-sistem ini mempunyai beberapa fasilitas pelayanan pada setiap tahapnya

Buku tamu yang digunakan pada perpustakaan Stikes alifah padang merupakan buku tamu fisik yang diisi oleh pengunjung, baik anggota (mahasiswa, dosen dan staf) maupun tamu yang datang berkunjung. Informasi yang terangkum di dalamnya adalah tanggal kunjungan, nama pengunjung, no identitas (NIM bagi mahasiswa dan NIK bagi staf / dosen) dan paraf.

Buku tamu ini ditempatkan di dekat pintu masuk perpustakaan. Selain buku tamu fisik terdapat pula buku tamu (guest book) yang disediakan di sistem informasi perpustakaan yang diperuntukkan bagi pengunjung website perpustakaan. Untuk mengatasi berbagai permasalahan dalam penggunaan buku tamu elektronik, diperlukan suatu teknik baru dalam perekaman data pengunjung di perpustakaan yang memanfaatkan teknologi informasi. Buku Tamu elektronik memiliki keunggulan berupa kemampuan merekam data pengunjung secara lebih cepat dan akurat, dan menghasilkan informasi sesuai jumlah kunjungan yang terjadi. Buku Tamu Elektronik yang akan di rancang ditujukan untuk mempercepat proses perekaman data pengunjung melalui penggunaan teknologi barcode, sehingga dapat mengurangi antrian, mempercepat proses pengolahan informasi dan menyimpan informasi yang lebih lengkap, seperti profil pengunjung, tingkat kepuasan terhadaplayanan, sarana penunjang dan kelengkapan dan kemudahan memperoleh bahan bacaan yang diperlukan.

\section{DAFTAR PUSTAKA}

Danu Winarko, Pembuatan Aplikasi Buku Tamu Elektronik Menggunakan C\#.Net dan Mysql, perpustakaan Gunadarma: Ilmu Komputer, 2013, (online), diakses pada situs http://library.gunadarma.ac.id/ repository/view/3757405/pembuatana p l i k a s i - b u k u - t a m u elektronikmenggunakan-cnet-danmysql.html/ (pada tanggal 9 Juni 2015)

Nasrul Lubis. RA, Sistem Aplikasi Buku Tamu Balittro Sebagai Pendataan Pengunjung Perpustakaan, ( Jatinangor: Fikom Unpad, 2007 ), hlm. 51

Rushendi, Buku tamu Digital (digital Guestbook) Sebagai Penunjang Pelayanan pengguna di perpustakaan Balittro, Bogor: Balai Penelitian Tanaman Obat dan Aromatik, 2010. (online). Diakses pada situs http:// h317dy.wordpress.com/2010/11/05/ buku-tamu-digital-digital-guestbooksebagai-penunjang-pelayananpengguna-di-perpustakaan-balittro/ ( pada tanggal 2 Februari 2015).

Sunu, A. P. (2014). PERAN PERPUSTAKAAN DIGITAL DAN TEKNOLOGI INFORMASI DI ERA GLOBALISASI. Info Persadha, 12(1), 33-37. Retrieved from http:// ejournal.usd.ac.id/index.php/Info_Persa dha/article/view/34/30

Syihabuddin Qalyubi dkk., Dasar-Dasar Ilmu Perpustakaan dan Informasi, (Yogyakarta: UIN Sunan Kalijaga, 2007), hlm. 77 